\title{
Persepsi dan Tingkat Kepuasan Taruna terhadap Pelayanan pada Proses Pendidikan
}

\author{
[Perception and Taruna Satisfaction Level to Service on Educational Process] \\ Abdul Hanan ${ }^{\otimes}$, Walson H. Sinaga \\ Sekolah Tinggi Perikanan Jurusan Penyuluhan Perikanan \\ Jalan Cikaret No. 2 Bogor Selatan, Kota Bogor
}

Diterima :1 Nov 2017, Disetujui: 5 Desember 2017

\begin{abstract}
Abstrak
Hasil penelitian memperlihatkan berdasarkan 14 unsur pelayanan pendidikan kelompok dosen labo teknologi kepada taruna IKP optimal 3,000 namun range indek kepuasan taruna pada pendidikan yang diberikan dosen labo teknologi terendah 2,12 dan tertinggi 2,700. Sedangkan bagi responden taruni range IKPi yang diberikan terendah 2,200 dan tertinggi 3,00. Pada Kelompok dosen labo ekonomi pelayanan unsur terendah oleh taruna 2,15 dan tertinggi 2,700, sedangkan persepsi yang diberikan oleh taruni unsur terendah dengan nilai 2,15 dan tertinggi 3,00. Pada Kelompok Dosen labo penyuluhan persepsi taruna unsur terendah dengan nilai 2,200 dan tetinggi 3,00, sedangkan yang diberikan oleh taruni unsur terendah dengan nilai 2,300 dan unsur tertinggi dengan nilai 3,00. Nilai Indek Kepuasan Taruna (IKTa) bagi kelompok dosen labo teknologi diperoleh nilai sebesar 62,214, dengan kriteria kinerja Baik, sedangkan untuk Nilai Indek Kepuasan Tarunai (IKTi) sebesar 69,58, dengan kriteria kinerja Sangat Baik. Nilai Indek Kepuasan Taruna (IKTa) bagi kelompok dosen labo ekonomi sebesar 61,53, dengan kriteria kinerja Baik, sedangkan untuk Nilai Indek Kepuasan Taruni (IKTi) sebesar 68,865, dengan kriteria kinerja Sangat Baik. Nilai Indek Kepuasan Taruna (IKTa) bagi kelompok dosen labo penyuluhan sebesar 64,60, dengan kriteria kinerja sangat Baik,sedangkan untuk Nilai Indek Kepuasan Tarunai (IKTi) sebesar 70,025, dengan kriteria kinerja Sangat Baik.
\end{abstract}

Kata kunci:kepuasan, pelayanan,persepsi

\begin{abstract}
The results of the study show that based on 14 elements of educational process service by lecturers group of technological field to optimum IKP 3,000 cadets, however the range of cadets satisfaction index on educational process is given by the lowest technological lecturer 2.12 and the highest is 2,700. As for the respondents taruni IKPi range given the lowest 2,200 and the highest 3.00. In the group of lecturers economic field service the lowest element by the cadet 2.15 and the highest 2.700, while the perception given by taruni elements the lowest with a value of 2.15 and the highest 3.00. In the Lecturers Group, the lowest element of cadastre perception counselor with the value of 2,200 and the 3,00, while the taruni is given by the lowest element with the value 2,300 and the highest element with value 3,00 . The value of Taruna Satisfaction Index (IKTa) for lecturer group of technological labo obtained by 62,214 , with good performance criteria, while for Taruni Satisfaction Index Value (IKTi) is 69,58, with performance criteria is very good. The value of Taruna Satisfaction Index (IKTa) for the group of lecturers from economics field of 61.53, with good performance criteria, while for Taruni Satisfaction Index Value (IKTi) of 68.865, with performance criteria Excellent. The value of Taruna Satisfaction Index (IKTa) for group lecturer of counseling/extension field is 64,60, with very good performance criteria, while for Taruni Satisfaction index Value (IKTi) is 70,025, with performance criteria is very good.
\end{abstract}

Keywords: perception, satisfaction, service

\footnotetext{
Penulis korespondensi
}

Alamat surel: 


\section{PENDAHULUAN}

Pendidikan adalah usaha sadar untuk menumbuh-kembangkan potensi sumberdaya manusia melalui kegiatan pengajaran (Muhidin 2003). Persepsi dalam proses pendidikan adalah pemantauan terhadap pengetahuan, sikap, dan perilaku individu sasaran didik dan dampaknya pada peningkatan pelayanan.

Pemantauan persepsi mengukur manusia di tiga aspek, yaitu: (1) Pengetahuan yang dimiliki, baik yang didapat secara formal, informal atau dari pengalaman;(2) Sikap, Pengetahuan yang dimiliki seseorang akan membentuk sikap seseorang terhadap suatu hal; dan (3) Perilaku, Pengetahuan dan sikap dapat terejawantah dalam bentuk perilaku.

Terkait dengan pendidikan Reber (1988) mengemukakan teori dan masalah kependidikan antara lain: penerapan prinsip-prinsip belajar dalam kelas, pengembangan dan pembaruan kurikukum, ujian dan evaluasi, proses interkasi dan penyelenggaran pendidikan.

Proses pendidikan merupakan pelayanan dari pendidika ke sasaran didik, pelayanan publik bertalian dengan ketersediaan dan cara menyampaikan ber-bagai layanan dalam bentuk barang dan jasa publik yang telah ditentukan, dijanjikan atau diwajibkan kepada pe-nyelenggara pelayanan.
Ketersediaan berhubungan dengan jumlah atau kecukupan atas barang dan jasa publik yang seharusnya menjadi tanggung jawab penyedia layanan. Sedangan cara menyampaikan layanan publik adalah metoda, teknik atau sistem yang digunakan untuk menjamin pemenuhan kebutuhan pengguna layanan publik.

Permasalahan yang ditemukan pada proses pendidikan di Jurusan penyuluhan Perikanan Bogor merupakan fenomena yang menarik, dikarenakan terdapat unsurunsur yang sangat penting di dalamnya, khususnya pendidik dan materi pendidikan, dan karakteristik sasaran didik, serta sarana dan prsasarana pendidikan. Ke empat komponen tersebut saling berkaitan dalam keberhasilan proses pendidikan, namun belum ada data yang valid sebagai bahan kebijakan.

Kebehasilan belajar yang seringkali kurang diperhatikan dalam proses belajar antara lain: (1) Efisiensi belajar, yaitu konsep yang mencerminkan perbandingan terbaik antara usaha dengan hasilnya (Gie 1985);(2) Ragam pendekatan belajar (Ballar \& Clanchy 1990); dan (3) Metode belajar (Biggs 1991).

Tujuan dan kegunaan penelitian adalah sebagai berikut: a) menjelaskan hubungan pendidik dengan tingkat kepuasan taruna, b) menjelaskan hubungan materi pendidikan dengan kepuasan taruna, c) menganalisis tingkat kepuasan taruna 
terhadap proses pendidikan, d) menjelaskan hubungan antara jenis kelamin taruna dengan kepuasan terhadap proses pendidikan.

Adapun kegunaan dari penilitian ini, adalah: (1) memperoleh data tingkat kepuasan taruna sebagai sasaran pendidikan; dan (2) memberikan masukan pada intansi dalam rangka peningkatan proses pendidikan.

\section{BAHAN DAN METODE}

Penelitian dilakukan di Kampus Sekolah Tinggi Perikanan Jurusan Penyuluhan Perikanan Bogor. Penelitan dilakukan selama 8 minggu di Bulan Maret sampai April 2017. Responden pada penelitian ini adalah taruna tingkat IV (Taruna Utama) sebanyak 60orang.

Data yang dikumpulkan terdiri dari data primer dan data sekunder. Data primer dikumpulkan dengan wawancara kepada taruna menggunakan daftar pertanyaan (kuisioner) yang telah disiapkan, dan dilakukan juga wawancara mendalam (indepth interview) dengan petugas yang meberikan pelayanan di perpustakaan dan unit layanan kesehatan.

Analisa Indeks Kepuasan Taruna (IKT) dengan menggunakn nilai rata-rata tertimbang masing-masing unsur pelayanan. Dalam perhitungan IKT unsur pelayanan yang dikaji setiap unsur pelayanan memiliki penimbang yang sama dengan menggunakan rumus:

Bobot Nilai Rata-rata Tertimbang

= Jumlah bobot/Jumlah Unsur

$=1 / 14=0,071$

Sedangkan untuk memperoleh nilai IKT unit pelayanan digunakan pendekatan nilai rata-rata tertimbang dengan rumus sebagai berikut:

Total dari Nilai Persepsi Per Unsur X Nilai Tertimbang Total Unsur yang terisi

\section{HASIL DAN PEMBAHASAN}

Program Studi Penyuluhan Perikanan merupakan Disiplin Ilmu yang menangani permasalahan kompetensi sumberdaya manusia perikanan terkait aspek sosial ekonomi dan teknologi perikanan.

Oleh karena itu Ruang ling-kup kajian dari bidang ilmu sosial ekonomi dan teknologi perikanan. Kurikulum lokal yang termuat dalam kurikulum program studi disusun berdasarkan ciri keilmuan program studi Penyuluhan Perikanan, antara lain Dasar-dasar Penyuluhan Perikanan, Media Penyuluhan Perikanan, Metode Penyuluhan Perikanan,

Teknik Penyuluhan Perikanan, Programa Penyuluhan Perikanan. Selain itu, kesesuaian kurikulum dengan kebutuhan masyarakat dapat dilihat dari beberapa 
mata kuliah institusional yang juga menjadi bagian dari kompetensi ciri khusus lulusan Program Studi Penyuluhan Perikanan, yaitu Dasar-dasar Budidaya Perikanan, Pengelolaan Kualitas Air, Pakan Ikan, Reproduksi dan Genetika Ikan, Keteknikan Budidaya Perikanan, Kesehatan Ikan, Pembenihan Ikan Air Tawar, Pembenihan Ikan Air Payau dan Laut, Pembesaran Ikan Air Tawar, Pembesaran Ikan Air Payau dan Laut, Pengelolaan Produksi Perikanan Budidaya, dan Teknologi Pasca Panen Hasil Perikanan.

Dalam pelaksanaan proses belajar mengajar sesuai dengan kelompok keilmuan, maka sejumlah dosen mengelompokkan menjadi tiga kelompok keil-muan, yaitu 1) Kelompok Dosen dengan Keilmuan Sosial Penyuluhan, 2) Kelompok Dosen dengan keilmuan Teknologi perikanan dan 3) kelompok dosen dengan keilmuan bisnis perikanan.

Untuk melihat sejauhmana pelayanan proses pendidikan dosen dari masing- masing kelompok keilmuan dilakukan penelitian ini.

Hasil analisis tingkat Indek $\mathrm{Ke}$ puasan Taruna (IKP) terhadap 14 unsur pelayanan proses pendidikan dilakukan terhadap kelompok (labo) dosen yaitu Labo Teknologi, Labo Bisnis dan Labo Penyuluhan adapun hasil analisis dapat dilihat pada Tabel 1.

\section{Tingkat Pelayanan Pendidikan Dosen Labo teknologi}

Berdasarkan data pelayanan proses pendidikan dari labo teknologi yang diperoleh dari responden taruna dan taruni tersaji pada Tabel 2.

Pada Tabel 2 memperlihatkan bawa berdasarkan hasil analisis terhadap 14 unsur pelayanan proses pendidikan terhadap taruna IKP optimal 3,000, namun demikian kisaran indek kepuasan taruna terhadap proses pendidikan yang diberikan dosen labo teknologi terendah 2,12 dan tertinggi 2,70 .

Tabel 1. Nilai persepsi internal IKT, nilai intreval konversi, mutu pelayanan dan kinerja

\begin{tabular}{ccccc}
\hline $\begin{array}{c}\text { Nilai } \\
\text { Persepsi }\end{array}$ & Nilai Interval & $\begin{array}{c}\text { Nilai Interval } \\
\text { Konversi }\end{array}$ & Mutu Pelayanan & $\begin{array}{c}\text { Kinerja Unit } \\
\text { Pelayananl }\end{array}$ \\
\hline 1 & $1,00-1,60$ & $25-43,75$ & $\mathrm{C}$ & Kurang baik \\
2 & $1,70-2,30$ & $43,76-62,50$ & B & Baik \\
3 & $2,40-3,00$ & $62,51-81,25$ & A & Sangat baik \\
\hline
\end{tabular}


Tabel 2. Hasil Pengolahan data Indek kepuasan Taruna Untuk labo teknologi

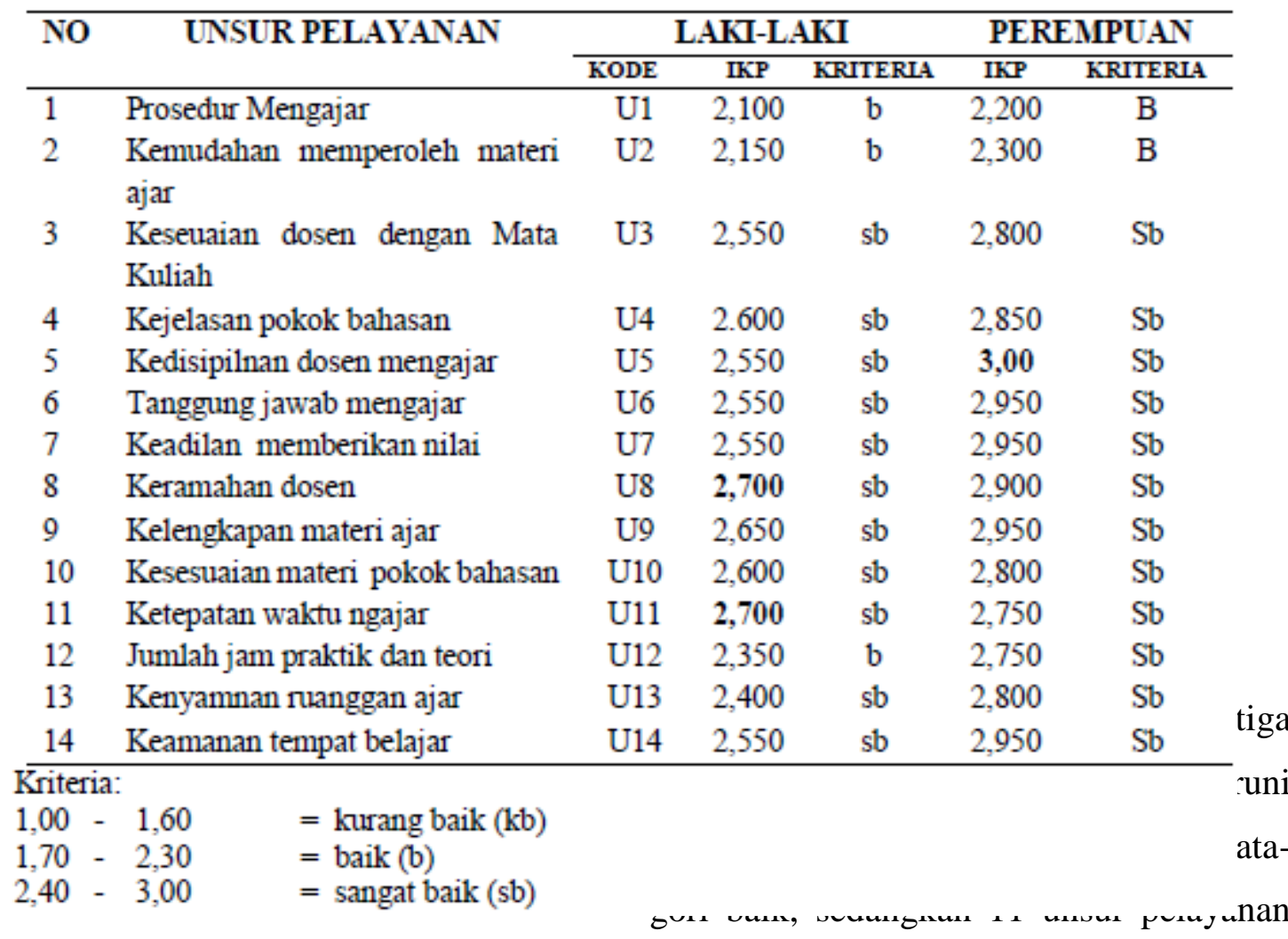

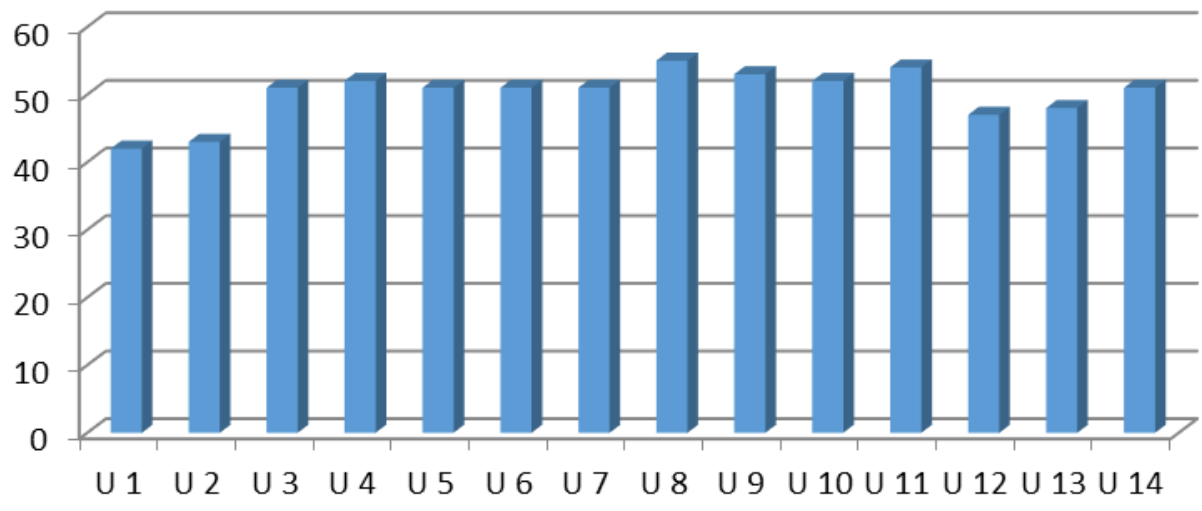

- Series 3

Series 2

- Series 1

Gambar 2. Perbandingan indek kepuasan tarunapada proses pendidikan labo teknologi

dengan mata kuliah yang diajar.

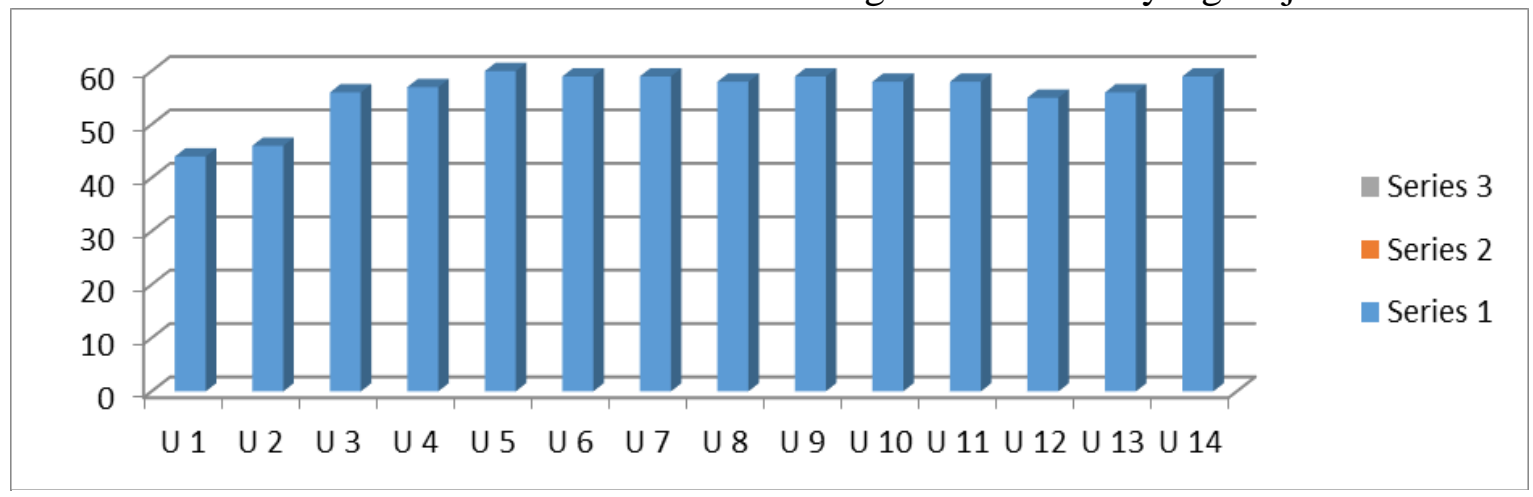

Gambar 3. Perbandingan indek kepuasan taruni pada proses pendidikan labo teknologi 
$(2,200)$ dan kemudahan memperoleh bahan ajar $(2,300)$.

Untuk mengetahui mutu pelayanan dan kinerja unit perpustakaan maka dilakukan analisis dengan rumus $\mathrm{U}^{\mathrm{n}} \times 0,0071$ dalam hal ini Un adalah nilai rata-rata per unsur pelayanan, dan 0,071 adalah nilai bobot rata-rata tertimbang seperti pada Gambar 2.

Pada grafik memperlihatkan bahwa nilai kepuasan tertinggi diperoleh pada unsur 8 (U8) yaitu keramahan dosen, sedangkan nilai kepuasn pelayanan yang paling rendah pada unsur 14 (U14) yaitu keamanan tempat belajar.
Pada grafik memperlihatkan bahwa nilai kepuasan ter-tinggi diperoleh pada unsur 5 (U) yaitu disiplin dosen dalam mengajar. Untuk mengetahui nilai indek pelayanan berupa mutu pelayanan dan kinerja dari unit perpustakaan Sekolah Tinggi Perikanan Jurusan Penyuluhan Perikanan Bogor dilaku-kan analisis dengan rumus:

Indeks pelayanan $=U^{n} \times 0,071$

Ket:

$\mathrm{U}^{\mathrm{n}}=$ Nilai rata-rata per unsur pelayanan $0,071=$ Nilai bobot rata-rata tertimbang

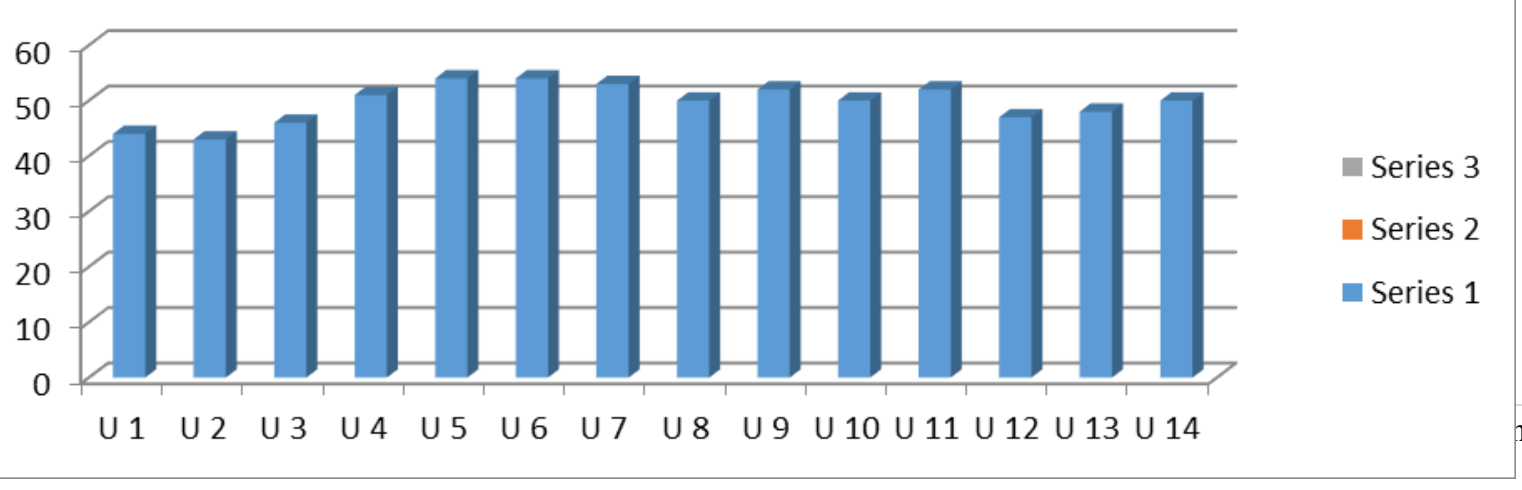

Gambar 4. Perbandingan Indek Kepuasan Taruna Pada Proses Pendidikan Labo Ekonomi 


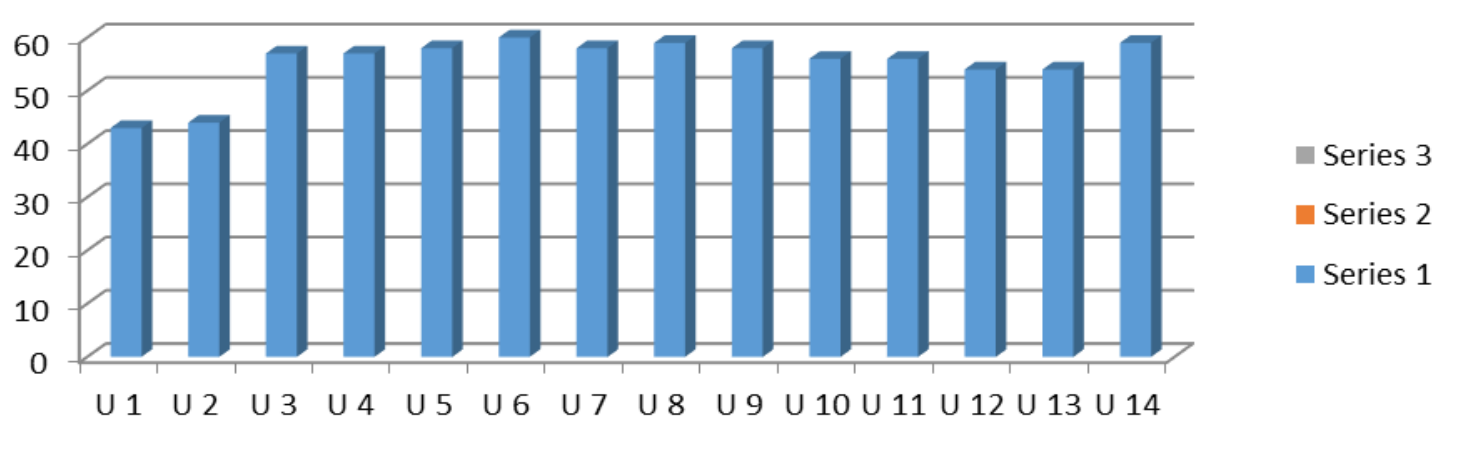

Gambar 5. Perbandingan indek kepuasan taruni pada proses pendidikan labo ekonomi

Tabel 3. Hasil pengolahan data indek kepuasan taruna untuk labo penyuluhan

\begin{tabular}{|c|c|c|c|c|c|c|}
\hline \multirow[t]{2}{*}{ NO } & \multirow[t]{2}{*}{ UNSUR PELAYANAN } & \multicolumn{3}{|c|}{ LAKI-LAKI } & \multicolumn{2}{|c|}{ PEREMPUAN } \\
\hline & & KODE & IKP & KRITERIA & IKP & KRITERIA \\
\hline 1 & Prosedur Mengajar & U1 & 2,200 & $\mathrm{~b}$ & 2,150 & $\mathrm{~b}$ \\
\hline 2 & $\begin{array}{l}\text { Kemudahan memperoleh materi } \\
\text { ajar }\end{array}$ & $\mathrm{U} 2$ & 2,150 & $\mathrm{~b}$ & 2,200 & $\mathrm{~b}$ \\
\hline 3 & $\begin{array}{l}\text { Keseuaian dosen dengan Mata } \\
\text { Kuliah }\end{array}$ & U3 & 2,300 & $\mathrm{~b}$ & 2,850 & $\mathrm{Sb}$ \\
\hline 4 & Kejelasan pokok bahasan & U4 & 2,550 & $\mathrm{sb}$ & 2,850 & $\mathrm{Sb}$ \\
\hline 5 & Kedisipilnan dosen mengajar & U5 & 2,700 & $\mathrm{sb}$ & 2,900 & $\mathrm{Sb}$ \\
\hline 6 & Tanggung jawab mengajar & U6 & 2,700 & $\mathrm{sb}$ & 3,000 & $\mathrm{Sb}$ \\
\hline 7 & Keadilan memberikan nilai & $\mathrm{U} 7$ & 2,650 & $\mathrm{sb}$ & 2,900 & $\mathrm{Sb}$ \\
\hline 8 & Keramahan dosen & U8 & 2,500 & $\mathrm{sb}$ & 2,950 & $\mathrm{Sb}$ \\
\hline 9 & Kelengkapan materi ajar & U9 & 2,600 & $\mathrm{sb}$ & 2,900 & $\mathrm{Sb}$ \\
\hline 10 & Kesesuaian materi pokok bahasan & U10 & 2,500 & $\mathrm{sb}$ & 2,947 & $\mathrm{Sb}$ \\
\hline 11 & Ketepatan waktu ngajar & U11 & 2,600 & $\mathrm{sb}$ & 2,800 & $\mathrm{Sb}$ \\
\hline 12 & Jumlah jam praktik dan teori & U12 & 2,350 & $\mathrm{sb}$ & 2,700 & $\mathrm{Sb}$ \\
\hline 13 & Kenyamnan ruanggan ajar & U13 & 2,400 & $\mathrm{sb}$ & 2,700 & $\mathrm{Sb}$ \\
\hline 14 & Keamanan tempat belajar & U14 & 2,500 & $\mathrm{sb}$ & 2,950 & $\mathrm{Sb}$ \\
\hline $\begin{array}{l}1 . \\
2 . \\
3 . \\
4 .\end{array}$ & $\begin{array}{l}\text { Sriteria: } \\
1,00-1,60 \\
, 70-\quad 2,30 \\
40-3,00\end{array}$ & & & & & \\
\hline
\end{tabular}

$(2,200 \times 0,071)+(2,300 \times 0,071)+(2,800 \times 0,071)+(2,850 \times 0,071)+(3,000 \times 0,071)+(2,950 \times 0,071)+$ $(2,950 \times 0,071)+(2,900 \times 0,071)+(2,950 \times 0,071)+(2,800 \times 0,071)+(2,800 \times 0,071)+(2,750 \times 0,071)+$ $(2,800 \times 0,071)+(2,950 \times 0,071)=$ nilai indek adalah 2,783

$(2,100 \times 0,071)+(2,150 \times 0,071)+(2,550 \times 0,071)+(2,600 \times 0,071)+(2,550 \times 0,071)+(2,550 \times 0,071)+$ $(2,550 \times 0,071)+(2,750 \times 0,071)+(2,650 \times 0,071)+(2,600 \times 0,071)+(2,700 \times 0,071)+(2,350 \times 0,071)+$ $(2,400 \times 0,071)+(2,550 \times 0,071)=$ nilai indek adalah 2,489 


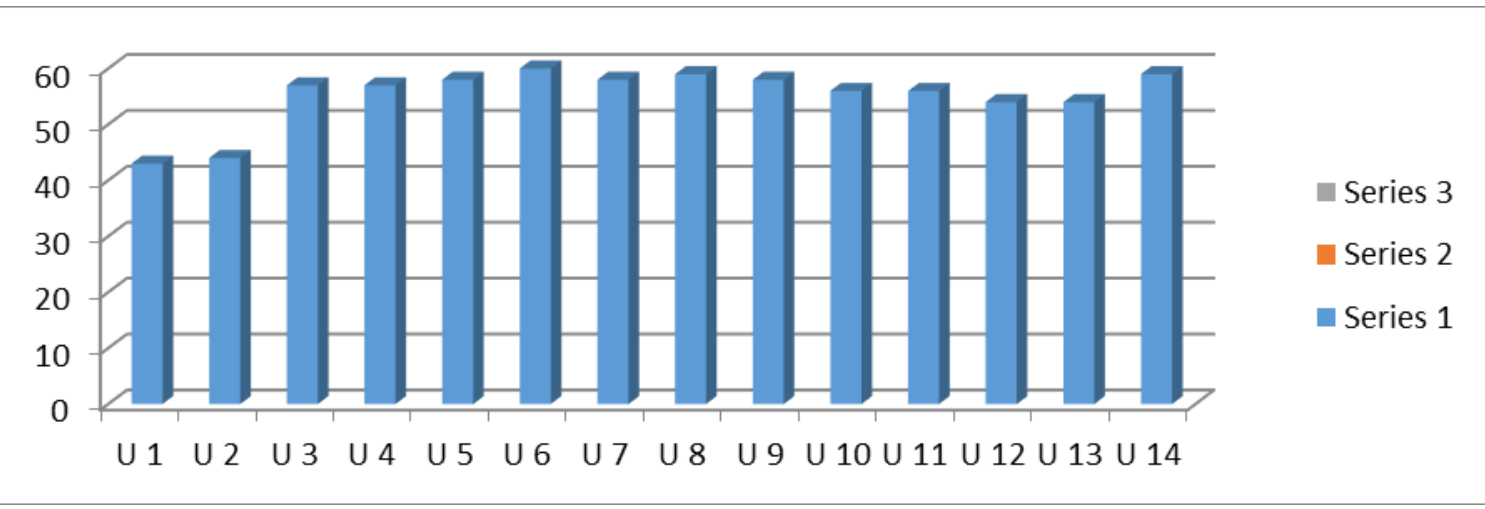

Gambar 5. Perbandingan indek kepuasan taruni pada proses pendidikan labo ekonomi

Berdasarkan hasil perhitungan maka Nilai Indek Kepuasan Taruna (IKTa) setelah dikonversi $=2,489 \times 25=62,214$ hal tersebut menunjukkan bahwa mutu pelayanan proses pendidikan untuk kelompok dosen pada lobo teknologi Sekolah Tinggi Perikanan Jurusan Penyuluhan Perikanan Bogor pada kategori B, dengan kriteria kinerja Baik.

Sedangkan untuk Nilai Indek Kepuasan Tarunai (IKTi) setelah dikonversi $=2,783 \times 25=69,58$ hal tersebut menunjukkan bahwa mutu pelayanan proses pendidikan untuk kelompok dosen pada lobo teknologi Sekolah Tinggi Perikanan Jurusan Penyuluhan Perikanan Bogor pada katagori A, dengan kriteria ki-nerja Sangat Baik.

\section{Tingkat Pelayanan Pendidikan Dosen Labo Ekonomi}

Berdasarkan tabulasi hasil penelitian terhadap responden pelayanan proses pendidikan yang diberikan kelompok dosen ekonomi seperti pada Tabel 3.
Pada Tabel 3 memperlihatkan bawa berdasarkan hasil analisis terhadap 14 unsur pelayanan proses pendidikan terhadap taruna sebagai sasaran didik nilai terendah 2,15 dan tertinggi 2,700. Terdapat tiga unsur yang dinilai oleh taruna baru sampai katagori baik,dan dua unsur yang dinilai oleh taruni, sedangkan 12 unsur pelayanan lainnya dinilai sangat baik.

Hasil penelitian memperlihatkan bagi taruna yang dinilai pelayanan dengan katagori baik yaitu: cara mengajar dosen $(2,200)$, kemudahan memperoleh materi ajar $(2,150)$ dari dosen, dan kesesuian dosen dengan mata kuliah yang diajar $(2,300)$, sedangkan pendapat taruni nilai terendah 2,15 dan tertinggi 3,00. Terdapat dua unsur yaitu cara mengajar $(2,150)$ dan kemudahan memperoleh mate-ri ajar $(2,200)$.

Untuk mengetahui mutu pelayanan dan kinerja unit perpustakaan maka dilakukan analisis dengan rumus $\mathrm{U}^{\mathrm{n}} \mathrm{x} 0,0071$ dalam hal ini Un adalah nilai rata-rata per 
unsur pelayanan, dan 0,071 adalah nilai bobot rata-rata tertimbang Pada grafik memperlihatkan bahwa nilai kepuasan tertinggi diperoleh pada unsur 5 (U5) dengan nilai 54 yaitu kedisiplinan dosen, sedangkan nilai kepuasn pelayanan yang paling rendah pada unsur 6 (U6) dengan nilai 54 yaitu tanggung jawab dosen.

Pada grafik memperlihatkan bahwa nilai kepuasan tertinggi diperoleh pada unsur 6 (U6) yaitu tanggung jawab dengan skor 60, unsur ke 8 (U8) yaitu keramahan dosen dalam mengajar dengan skor 59.

Dan unsur 14 (U14) tempat berlajar yang aman dengan skor 59. Untuk mengetahui nilai indek pelayanan berupa mutu pela-yanan dan kinerja dari unit perpustakaan Sekolah Tinggi Perikanan Jurusan Penyu-luhan Perikanan Bogor dilakukan analisis dengan rumus yang sama.

Berdasarkan hasil perhitungan maka Nilai Indek Kepuasan Taruna (IKTa) setelah dikonversi $=2,464 \times 25=61,593$ hal tersebut menunjukkan bahwa mutu pelayanan proses pendidikan untuk kelom-pok dosen pada labo teknologi Sekolah Tinggi Perikanan Jurusan Penyuluhan Pe-rikanan Bogor pada katagori $\mathrm{B}$, dengan kriteria kinerja Baik. Sedangkan untuk Nilai Indek Kepuasan Taruna (IKTi) setelah dikonversi $=2,755 \times 25=68,865$ hal tersebut menunjukkan bahwa mutu pelayanan proses pendidikan untuk kelompok dosen pada labo teknologi Sekolah Tinggi Perikanan Jurusan Penyuluhan Perikanan Bogor pada katagori A, dengan kriteria kinerja Sangat Baik.

\section{Tingkat Pelayanan Pendidikan Dosen labo Penyuluhan}

Berdasarkan tabulasi hasil penelitian terhadap responden taruna dan taruni terhadap pelayanan proses pendidikan yang diberikan kelompok dosen penyuluhan dapat dilihat pada Tabel 4.

Pada Tabel 4 memperlihatkan bawa berdasarkan hasil analisis terhadap 14 unsur pelayanan proses pendidikan terhadap taruna sebagai sasaran didik nilai terendah diperoleh sebesar 2,200 dan tertinggi 3,00, sedangkan responden taruni memberikan nilai terendah sebesar 2,300 dan tertinggi 3,00 .

Terdapat dua unsur yang dinilai oleh taruna dan taruni meperoleh indek kepuasaan dengan katagori baik, sedangkan 12 unsur pelayanan lainnya dinilai sangat baik. Hasil penenelitian memperlihatkan bagi taruna yang dinilai pelayanan dengan katagori baik yaitu kemudahan memperoleh materi ajar $(2,200)$ dari dosen, dan kesesuian dosen dengan mata kuliah yang diajar (2,368), sedangkan pendapat taruni pada unsur proses mengajar dan kesesuain dosen dengan mata kuliah yang diajar. 
Hasil Perhitungan untuk Responden Taruna

$(2,200 \times 0,071)+(2,150 \times 0,071)+(2,300 \times 0,071)+(2,550 \times 0,071)+(2,700 \times 0,071)+(2,700 \times 0,071)+$

$(2,650 \times 0,071)+(2,500 \times 0,071)+(2,600 \times 0,071)+(2,500 \times 0,071)+(2,600 \times 0,071)+(2,350 \times 0,071)+$

$(2,400 \times 0,071)+(2,500 \times 0,071)=$ nilai indek adalah 2,464

Hasil Perhitungan untuk Responden Taruni

$(2,150 \times 0,071)+(2,200 \times 0,071)+(2,850 \times 0,071)+(2,850 \times 0,071)+(2,900 \times 0,071)+(3,000 \times 0,071)+$

$(2,900 \times 0,071)+(2,950 \times 0,071)+(2,900 \times 0,071)+(2,940 \times 0,071)+(2,800 \times 0,071)+(2,700 \times 0,071)+$

$(2,700 \times 0,071)+(2,950 \times 0,071)=$ nilai indek adalah 2,755

Tabel 4. Hasil Pengolahan data Indek kepuasan Taruna Untuk labo Penyuluhan

\begin{tabular}{|c|c|c|c|c|c|c|}
\hline \multirow{2}{*}{ No } & \multirow{2}{*}{ UNSUR PELAYANAN } & \multicolumn{3}{|c|}{ LAKI-LAKI } & \multicolumn{2}{|c|}{ PEREMPUAN } \\
\hline & & KODE & IKP & KRITERIA & IKP & KRITERIA \\
\hline 1 & Prosedur Mengajar & U1 & 2,400 & sb & 2,300 & B \\
\hline 2 & $\begin{array}{l}\text { Kemudahan memperoleh materi } \\
\text { ajar }\end{array}$ & $\mathrm{U} 2$ & 2,200 & $\mathrm{~b}$ & 2,350 & B \\
\hline 3 & $\begin{array}{l}\text { Keseuaian dosen dengan Mata } \\
\text { Kuliah }\end{array}$ & U3 & 2,368 & $\mathrm{~b}$ & 2,900 & $\mathrm{Sb}$ \\
\hline 4 & Kejelasan pokok bahasan & U4 & 2,800 & $\mathrm{sb}$ & 2,950 & $\mathrm{Sb}$ \\
\hline 5 & Kedisipilnan dosen mengajar & U5 & 2,600 & $\mathrm{sb}$ & 2,900 & $\mathrm{Sb}$ \\
\hline 6 & Tanggung jawab mengajar & U6 & 2,800 & $\mathrm{sb}$ & 2,950 & $\mathrm{Sb}$ \\
\hline 7 & Keadilan memberikan nilai & U7 & 2,700 & $\mathrm{sb}$ & 3,000 & $\mathrm{Sb}$ \\
\hline 8 & Keramahan dosen & U8 & 2,550 & $\mathrm{sb}$ & 2,950 & $\mathrm{Sb}$ \\
\hline 9 & Kelengkapan materi ajar & U9 & 2,800 & $\mathrm{sb}$ & 2,900 & $\mathrm{Sb}$ \\
\hline 10 & Kesesuaian materi pokok bahasan & $\mathrm{U} 10$ & 2,600 & $\mathrm{sb}$ & 2,950 & $\mathrm{Sb}$ \\
\hline 11 & Ketepatan waktu ngajar & U11 & 2,700 & $\mathrm{sb}$ & 2,800 & $\mathrm{Sb}$ \\
\hline 12 & Jumlah jam praktik dan teori & $\mathrm{U} 12$ & 2,500 & $\mathrm{sb}$ & 2,800 & $\mathrm{Sb}$ \\
\hline 13 & Kenyamnan ruanggan ajar & U13 & 2,600 & $\mathrm{sb}$ & 2,800 & $\mathrm{Sb}$ \\
\hline 14 & Keamanan tempat belajar & U14 & 2,750 & $\mathrm{sb}$ & 2,900 & $\mathrm{Sb}$ \\
\hline
\end{tabular}

\section{Kriteria:}

$1,00-1,60=$ kurang baik $(\mathrm{kb})$

$1,70-2,30=$ baik (b)

$2,40-3,00=$ sangat baik $(\mathrm{sb})$

Untuk mengetahui mutu pelayanan dan kinerja unit perpustakaan maka dilakukan analisis dengan rumus $U^{n} \times 0,0071$ dalam hal ini Un adalah nilai rata-rata per unsur pelayanan, dan 0,071 adalah nilai bobot rata-rata tertimbang
Pada grafik memperlihatkan bahwa nilai kepuasan tertinggi diperoleh pada unsur 5 (U5) yaitu tanggung jawab petugas pelayanan, sedangkan nilai kepuasan pelayanan yang paling rendah pada unsur 10 (U10) yaitu kelengkapan buku yang dibutuhkan. 
Untuk mengetahui nilai indeks pelayanan berupa mutu pelayanan dan kinerja dari unit Perpustakaan Sekolah Tinggi Bogor dilakukan dengan analisis rumus yang sama. Berdasarkan hasil perhitungan maka Nilai Indek Kepuasan Taruna (IKTa) setelah dikonversi $=2,584 \times 25=64,60$. Sedangkan untuk Nilai Indek Kepuasan Tarunai (IKTi) setelah dikonversi $=2,801$ x $25=70,025$.

Hal tersebut menunjukkan bahwa mutu pelayanan proses pendidikan untuk kelompok dosen pada labo penyuluhan Sekolah Tinggi Perikanan Jurusan Penyuluhan Perikanan Bogor pada dinilai oleh taruna maupun taruni katagori $\mathrm{A}$, dengan kriteria kinerja Sangat Baik.

Perbandingan Nilai kepuasan Taruna dan taruni terhadap kinerja proses pendidikan oleh ke tiga kelompok dosen keilmuan seperti pada grafik Gambar

Pada grafik memperlihatkan bahwa persepsi taruna terhadap proses pendidikan pada range 61,59 sampai 64,60. Penilaian yang diberikan taruna terhadap kelompok dosen pada tiga labo keilmuan paling tinggi 64,60 diberikan pada dosen kelompok keilmuan penyuluhan, dan terendah 61,59 diberikan pada dosen kelompok kelimuan ekonomi.

Sedangkan untuk responden taruni paling range nilai dari 68,86 sampai 70,25. Tertinggi diperoleh kelompok dosen keilmuan penyuluhan dan terendah kelompok dosen keilmuan ekonomi. Fenomena ting-kat kepuasan sasaran didik baik untuk sasaran didik jenis kelamin laki-laki (taruna) maupun sasaran didik perempuan (taruni) menunjukkan ada tingkat kepuasan yang berbeda, walaupun secara kuantitatif tidak berbda besar.

Berkaitan dengan persepsi sasaran didik dalam memerima pelayanan pendidikan, Menurut Silvia dalam Tubbs (2001) beberapa faktor yang berhubungan dengan persepsi seseorang antara lain budaya, gender, dan daya tarik fisik. $\mathrm{Bu}-$ daya dalam hal ini dikatakan orang-orang

\section{Hasil Perhitungan untuk Responden Taruna}

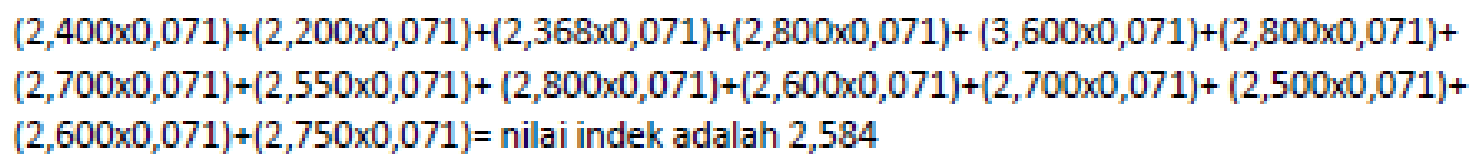

\section{Hasil Perhitungan untuk Responden Taruni}


Tabel 5. Nilai persepsi interval IKT, nilai interval konversi, mutu pelayanan dan kinerja unit pelayanan

\begin{tabular}{ccccc}
\hline $\begin{array}{c}\text { Nilai } \\
\text { Persepsi }\end{array}$ & Nilai Interval & $\begin{array}{c}\text { Nilai Interval } \\
\text { Konversi }\end{array}$ & $\begin{array}{c}\text { Mutu } \\
\text { Pelayanan }\end{array}$ & $\begin{array}{c}\text { Kinerja Unit } \\
\text { Pelayananl }\end{array}$ \\
\hline 1 & $1,00-1,60$ & $25-43,75$ & $\mathrm{C}$ & Kurang baik \\
2 & $1,70-2,30$ & $43,76-62,50$ & $\mathrm{~B}$ & Baik \\
3 & $2,40-3,00$ & $62,51-81,25$ & $\mathrm{~A}$ & Sangat baik \\
\hline
\end{tabular}

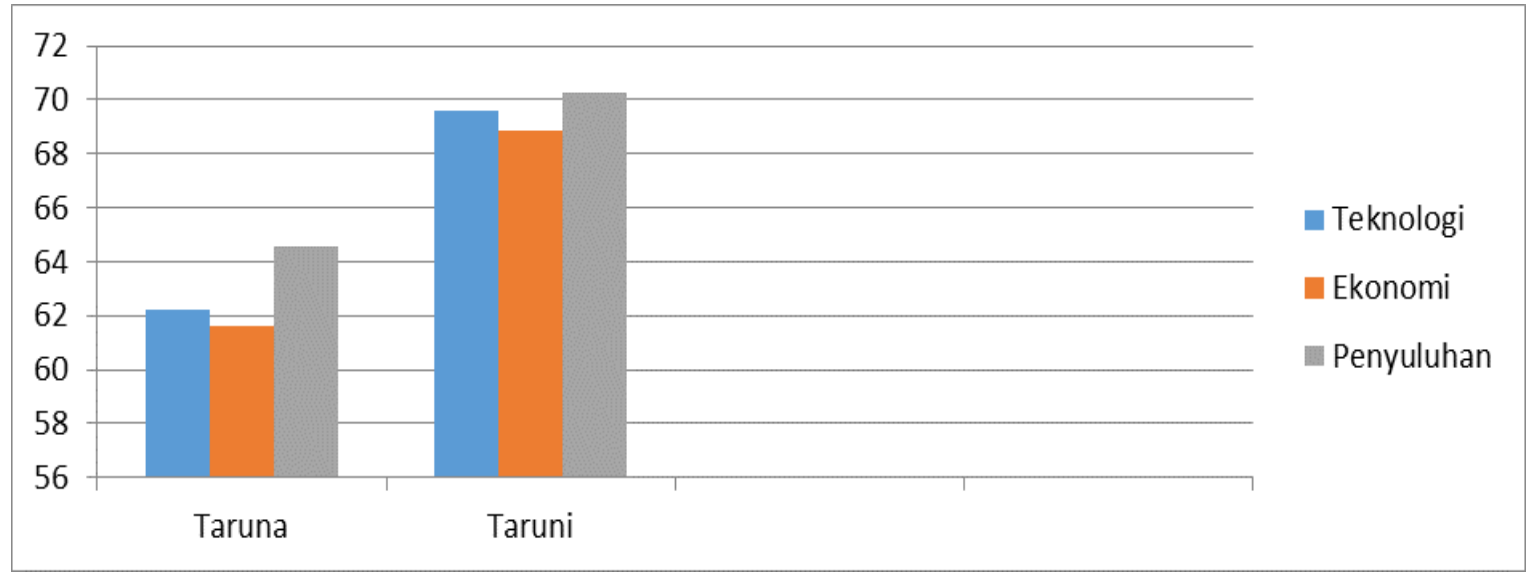

Gambar 6. Perbandingan Indek Kepuasan Taruna dengan Taruni

yang hidup dalam lingkungan budaya yang amat jarang memiliki struktur garis lurus dan sudut, mereka cenderung menafsirkan sudut lancip dan sudut tumpul sebagai sudut siku-siku yang diperluas dalam ruang. Pengaruh jenis kelamin (gender) dikatakan bahwa wanita dipanda-ng lebih suportif daripada pria. Daya tarik fisik, dalam hal ini disebutkan bahwa petugas yang menarik secara fisik (cantik, ganteng) dianggap lebih ramah, lebih populer, lebih seksi, lebih sukses dan lebih meyakinkan.

Berdasarkan hasil kajian pelayanan kelompok dosen dari ketiga labo (labo teknologi, labo ekonomi dan labo penyuluhan) terjadi perbedaan tingkat kepuasan, hal tersebut berhubungan kontribusi masing-masing dosen di dalam kelompoknya, hal tersebut sebagaimana disebutkan Sina- mo (2004) kegiatan pelayanan hasil pekerjaan dalam pelayanan tersebut seharusnya melampaui harapan pelanggan (sasaran didik).

Selanjutnya disebutkan ada tiga cara untuk memuaskan sasaran didik: Pertama, fokus pada yang dilayani (sasaran didik), karena mutu pelayanan didefinisiakn oleh sasaran didik yang dilayani, karena tanpa penerimaan sasaran didik usaha pelayanan akan berhenti.

Kedua, bahwa hasil kerja harus memenuhi kebutuhan sasaran didik yaitu harus dihasilkan oleh serangkaian langkah logis rasional yang setiap elemen proses tersebut juga harus bermutu. Keti-ga, adanya keterlibatkan semua komponen dalam suatu instansi dalam peningkatan mutu pelayanan. 
Pelayanan menurut Sina-mo (2004) merupakan kegiatan mulia "kemuliaan datang dari pelayanan" dan orang yang melayani adalah orang yang mulia. Terkait dengan pendapat tersebut seharusnya petugas di unit-unit pelayanan harus menyadari bahwa melalui pekerja-annya dapat memuliakan Tuhan, negara, bangsa dan keluarganya.

Sudah seharusnya petugas bersikap rendah hati dalam me-layani dengan penuh rasa hormat, sehingga yang dilayanai (klien) dapat dipuaskan. Selanjutnya Sinamo (2004) menyebutkan bahwa beberapa sikap kerja mulia yang harus dilakukan oleh petugas pelayanan yaitu: keseriusan, sungguh-sunguh, jujur, hemat, bertangung jawab dan teliti.

Pelayanan publik yang dirasakan masyarakat pada umumnya menyampaikan mengalami kesenjangan antara "harapan" dan "kenyataan".

Nilai kesenjangan hampir sama untuk ke lima dimensi pelayanana (service quality) sebagaimana dinyatakan Zeithaml, parasurtatman, Berry (1990) dalam Yustina \& Adjat (2003) yaitu: 1) Tangible, berkaitan dengan pelayanan yang terlihat oleh indera, dari mulai peralatan teknoogi yang dipergunakan hingga ke penampilan aparat, 2) Realibility, berkaitan dengan kehandalan suatu pelayanan yang tercermin pada profesionalitas dan penguasaan layanana oleh para aparat, 3) Respon- sibility, berkaitan dengan tanggung jawab terhadap kebutuhan pelanggan, tanggap terhadap berbagai keluhan masyarakat, 4) Assrance, berkaitan dengan kepercayaan masyarakat terhadap pelayan-an, dan 5) Empathy, yakni menyangkut aspek keramahan petugas, perhatian, dan pelayanan yang tulus serta penuh kesungguhan.

\section{SIMPULAN}

1. Kepuasan taruna terhadap pelayanan proses pendidikan di Jurusan Penyuluhan Perikanan untuk labo teknologi dinilai oleh taruna katagori baik $(62,215)$, sedangkan taruni memberikan nilai sangat baik $(69,58)$.

2. Kepuasan taruna terhadap pelayanan proses pendidikan di Jurusan Penyuluhan Perikanan untuk labo ekonomi dinilai oleh taruna katagori baik $(61,59)$, sedangkan taruni memberikan nilai sangat baik $(68,86)$.

3. Kepuasan taruna terhadap pelayanan proses pendidikan di Jurusan Penyuluhan Perikanan untuk labo penyuluhan dinilai oleh taruna katagori baik $(64,60)$, sedangkan taruni memberikan nilai sangat baik $(70,25)$.

4. Rata-rata unsur cara mengajar dan kemudahan memperoleh materi ajar yang belum sangat baik dalam proses.

5. Tiga kegiatan pelayanan pendidikan untuk memuaskan sasaran didik: a) fokus pada yang dilayani (sasaran di- 
dik), b) hasil kerja dihasilkan oleh serangkaian langkah logis rasional yang setiap elemen proses tersebut juga harus bermutu, dan c) adanya keterlibatkan semua komponen dalam suatu instansi dalam peningkatan mutu pelayanan.

\section{SARAN}

1. Untuk peningkatan pelayanan proses pendidikan terhadap sasaran didik maka fungsi utama sebagai dosen perlu dijalankan dengan sebaik-baiknya.

2. Perlu dilakukan monitoring secara periodik (per semester) indek kepuasan sassaran didik.

\section{PERSANTUNAN}

Ucapan terima kasih disampaikan kepada Ketua Jurusan Penyuluhan Perikanan Sekolah Tinggi Perikanan atas fasilitasi yang diberikan untuk melakukan penelitian ini.

\section{DAFTAR PUSTAKA}

Anonimous, 2012. Modul Diklat Pelayanan Publik. Pusdiklat SPIMNAS Bidang Manajemen dan Kebijakan Pem-bangunan. Lembaga Administrasi Negara.

2012. Peraturan Menteri Pemberdayaan Apartur Negara Dan Reformasi Biriokasi No. 36 tahun 2012. Petunjuk Teknis Penyusunan, penetapan, dan Penerapan Standar Pelayanan. Kemen PAN dan RB RI 2012.

Ballar B,C John. 1984. Study Abroad; A Manual for Asian Students. Selangor
Darul Ehsan. Longman Ma-laysia SDN. BHD.

Biggs JB. 1985. The Role of Metalearning Study Process. British Journal of Educational Psychology.

Gie, The Liang. 1985. Cara Belajar yang Efisien.Yogyakarta. Pusat Kemajuan Studi (Center for Study Progress).

Ida Y.Adjat S. 2003. Membentuk Pola Perilaku Manusia Pembangunan. IPB Press.

Kerlinger FN. 2002. Asas-asas Penelitian Behavioral. Diterjemahkan landing R. Simatupang. Yogyakarta: Gajah mada University Press.

Mcload, 1989. The new collins Dictionary and Thesaurus. Glasgow. William Collins Sons \& Co Ltd.

Reber Arthur S. 1988. The Penguin Dictionary of psychology. Ringwood Victoria. Penguin Books Australia Ltd.

Rogers EM, FF Shoemaker. 1987. Memasyarakatkan Ide-Ide baru. Disarikan oleh Abdillah Hanafi. Surabaya: Usaha Nasional.

Jansen H. Sinamo, 2004. Etos Kerja Profesional di Era Digital Global. Penerbit Institut Darma Mahardika. Jakarta.

Muhidin S. 2003. Psikologi Pendidikan dengan pendekatan baru. PT Remaja Rosdakarya. Bandung.

Sylvia M, Stewart LT, 2001. Human Commucation. Prinsisp-prinsip Da-sar Pengantar Dedy Mulayana. PT Remaja Rosdakarya. Bandung.

Van den Ban, HS Hawkins. 1998. Penyuluhan Pertanian. Agnes D Herdiastuti, penerjemah. dari Agricultural Extention. Kanasius Yogyakarta. 